\title{
Reasons for the Improvement of Labor Productivity in Tea Plantations after Privatization with Special Reference to the Estate Laborers in the Ratnapura District
}

\author{
S.Kodithuwakku ${ }^{1}$ and H.M.S.Priyanath ${ }^{2}$ \\ ${ }^{1}$ Department of Accountancy and Finance, Sabaragamuwa University of Sri \\ Lanka, Belihuloya \\ ${ }^{2}$ Department of Social Sciences, Sabaragamuwa University of Sri Lanka, \\ Belihuloya
}

\begin{abstract}
This paper attempts to discuss the reasons for the improvement of labor productivity after the privatization. This study mainly based on the primary data gathered from the laborers employed in tea estates in the Ratnapura district in Sri Lanka. 120 of laborers are selected representing 40 laborers from 03 privatized estates situated in the Ratnapura District. Data was mainly collected through a structured questionnaire and analyzed qualitatively and quantitative techniques. The study reveals that the financial benefits i.e. salary, allowances, salary increments, overtime and loan facilities and non-financial facilitieswelfare facilities like housing, education, health, daycare centers, transport, electricity etc. provided by the management company for laborers are highly affected to the improvement of labor productivity through the increase of labor satisfaction. Labor satisfaction regarding financial and non-financial benefits was relatively very high. On the other hand, strict management and application of new technology for the factories affect the improvement of labor productivity. Finally, it can be concluded that the labor productivity in tea plantation sector has improved after privatization due to the improvement of labor satisfaction, strict management and application of new techniques of the private companies.

Key Words: Labor productivity, Privatization, Financial benefits, Non-financial facilities, Labor satisfaction.
\end{abstract}

\section{Introduction}

Tea cultivation in Sri Lanka commenced during the British colonial period in 1839 on an experimental basis. In 1867, commercial tea cultivation was started for the first time on eight hectares. From about 1884, the area planted under tea increased dramatically until the early 1950s. Thus tea emerged as the most important export crop compared with the other two major agricultural export crops that spurred Sri Lanka's economic growth during the last century. For more than century, Sri Lanka's tea industry has been the backbone of the island's economy contributing $40 \%$ of export revenue, $30 \%$ to the agricultural labor force and also Gross Domestic Production (GDP). Throughout most of this century, the country's development activities and the socio-economic progress have been closely linked with the tea industry. (Bandara, 1996:01). However, the dominance of the tea sector in the economy has been declining since late 1960s. The position Sri Lanka held in the world tea economy underwent significant changes between mid 1960s and early 1990s, with the country's share of the world market declining from $20 \%$ to $9.5 \%$ in 1993. (Bandara, 1996, 02). The contribution to GDP from this sector, which accounted for around $16.5 \%$ in the early 1970 s, had fallen to $13.5 \%$ in late 1970 s and to $5.6 \%$ in 1985 . This further decreased in late 1980 and in 1993 it was 2.1\% of the GNP (Bandara, 1997, 1519). 
There was no significant growth in total production in the tea sector of the country compared to the other major tea producing countries in the world. Further, the yield per hectare has been declining continually since the mid 1960s, fluctuating below the yield level obtained in 1963. Prior to 1992, the growth rate of output per employee was declining by $1.97 \%$ per annum between 1985- 1991 and the leaf intake per pluckier on state plantations in 1991 was about $13.52 \mathrm{~kg}$ per person a day, compared to $24.59 \mathrm{~kg}$ for private sector workers. (Bandara, 1996, 11). In anticipation in nationalization, private companies which owned the tea estates cut down on investment in replanting and factory modernization and neglected maintenance of the plantations after the 1950s were the reasons behind this bad situation. Further, in 1972 the government embarked on a policy of land reform under pressure from the rural peasantry also adversely affected to productivity particularly on tea and rubber estates. On the other hand, unchanged world market prices and rising costs, the profitability of tea continued to decline in the early 1970s. As a result, replanting rates were low and production and exports declined. Weak management, lack of autonomy in decision making, high taxation on tea exports to finance government expenditure in other sectors of the economy and inability to respond to changing consumption patterns in the market were the other important factors for the continued decline of the tea sector (Bandara, 1996, 17-19).

The tea sector is the most important sector in the economy, for it creates employment opportunities. Among the plantation economies, Sri Lanka has the third largest estate work force, next only to India and Brazil. Recent research studies place more than $10 \%$ of the active work force in the country being absorbed in the tea agro industry. (Siveran, 1996, 04). Therefore, the tea industry is the most labor intensive of the plantation industries, giving direct employment to about 700,000 workers on 194,000 hectares of land. In addition, at least another 200,000 are in indirect, tea-related employment. (Bandara, $1996,11)$. Because of these characteristics, there is no doubt that the labor is the most important factor, which affect to the productivity of tea plantation. Therefore, the productivity of labor is highly correlated with the total productivity of tea plantation. However, labor productivity recorded in tea plantations is low when compared with competitive labor markets both domestic and foreign. It has been declining significantly over the past few decades and Sri Lankan estate workers rank at the bottom of the international productivity tables.

The reasons explained above were the main causes for the privatization of tea plantation; especially to improve the productivity this was to have significant repercussion on the management of plantations, particularly on the raising of investment capital needed for the modernization of the plantations. In June 1992, on the basis of competitive bids, 23 local private companies were selected and they were requested to establish separate independent public companies known as Managing Agents to manage the Regional Plantation Companies on the profit sharing basis. The privatization of the estates was significantly different from the privatization of other state-owned enterprises. If not handle properly, privatization can result in further decline in production, productivity, profit and export earning, widespread unemployment and labor unrest. In 1995, the full risk and benefits of management was passed on to the private companies. The land was leased to the private sector for a period of 50 years. A clear improvement of the tea plantation sector was recorded after privatization. It is anticipated that private sector participation would encourage investments, replanting and investment in machinery and equipments in the plantation sector. With the improved management several privatized plantation companies have increase their labor 
productivity and profits. (Central Bank, 1998: 86). According to Siverarn (1996:04), total labor productivity increased rapidly after the privatization process. 1986 the labor revenue output was $498 \mathrm{~kg}$ and in 1992 it remained at a same rate $500 \mathrm{~kg}$ and after six years latter it has increased sharply up to $949 \mathrm{~kg}$ in1996. (Siveran, 1996:05) This study attempts to analysis the reasons for the improvement of labor productivity after the privatization of tea plantations in Sri Lanka.

\section{Methodology}

A complex phenomenon could be best approached through multiple data sources and methods since it improves the validity and the reliability of the research. Therefore, both primary and secondary data were obtained. As this is an empirical study a great attempt was made to collect primary data. Primary data was gathered from the laborers employed in estates in Ratnapura District. As a sample, employees in tea plantations of Ratnapura district were selected to collect primary data. There are 23 tea estates privatized all over the country, out of those 03 were situated in Ratnapura district. All of them were selected for the survey. All of the administrative officers and 120 randomly selected employees who were employed in 03 privatized tea plantations were interviewed. Multiple methods such as in-depth interviews with employees and administrative participant, group discussions, direct observation were used to collect primary data. In-depth interviews were aided by structured questionnaire. Secondary data is obtained from various sources such as Central Bank Reports, Reports of Department of Census and Statistics, Annual Reports of the privatized Tea Plantation Companies, relevant Articles and Magazines etc. Data was analyzed qualitatively and quantitatively.

\section{Results and Discussion}

The term "productivity" conjures up different images and different interpretations to deferent people and even segments of society. According to Solomon Fabricant 'Productivity' is a subject surrounded by considerable confusion. In the past there has been many attempts to find the relationship between inputs and outputs in the production process in order to formulate a definition for the word 'productivity'. Adam Smith in his book 'The wealth of nations' discussed the division of labor and specialization and explained thereby the meaning of productivity. However, the most of the people who speak about productivity conceive it only to terms of labor productivity. Sometimes they neglect the other factors like capital, raw materials and the means of production and look at labor as the sole factor that leads to productivity. However, this does not underestimate the importance that labor productivity holds in this vast field of producing. Labor productivity can be interpreted as the value of all output divided by man-hours of work. However, productivity is measured in terms of certain data. When the word productivity is used without any qualification, it is assumed as productivity of labor. Also, at the national level, or at the sector level, labor productivity is often measured in terms of physical output per work-hour. Productivity improvement depends upon how successfully we identify and use the main factors of the socio-production system. However, to improve the efficiency rate and labor productivity of the tea plantations one should identify the most important factors, which affect labor productivity. Especially, the labor 
efficiency, management efficiency and manufacturing \& operating efficiency directly affect labor productivity.

\section{Financial Benefits}

Wages and other incentives, non-wage benefits, experience, job satisfaction is the factors that are directly affected to the labor efficiency. Through out the last decade, $71.5 \%$ of the total labor cost was wages and $21 \%$ of the total cost was allowances. The remaining $7.5 \%$ was non-wage benefits such as housing, medical crèche, welfare etc. (Sivaran, 1996:08)

Especially, wages and other financial facilities provided with the job are the most important factors in improving labor productivity. In keeping with established practice, all pluckers throughout the Island in the estate sector receive the same basic wage even without having to fulfill the daily plucking target which is set by individual Superintendents in accordance with the field conditions on their estate. Additionally, they are paid overtime plucking, if required, as an "incentive" or "over target" rate in terms of Rs/Kg of green leaf exceeding the target. The basic wage paid for employees, which are the higher rate among the other tea producing countries. However the most of employees are satisfied with their salary schemes after the privatization. Further, the most of them are like to have the over target rate or incentives rather than the salary increments or overtime payments. Therefore, the over target rate or incentives are the most important method for increase the labor productivity. After privatization, the most of the tea plantation companies were implement this system. This situation directly affected the increase the labor productivity.

Table 01. The Satisfactory Level of Wages and Other Financial Incentives

\begin{tabular}{|c|c|c|c|c|c|c|}
\hline \multirow[t]{2}{*}{ Indicator } & \multicolumn{3}{|c|}{ Pre-Privatization Period } & \multicolumn{3}{|c|}{ Post-privatization Period } \\
\hline & Satisfied & Moderate & $\begin{array}{c}\text { Un } \\
\text { satisfied }\end{array}$ & Satisfied & Moderate & $\begin{array}{c}\text { Un } \\
\text { satisfied }\end{array}$ \\
\hline Number of hours of work per week & $34 \%$ & $33 \%$ & $33 \%$ & $68 \%$ & $10 \%$ & $22 \%$ \\
\hline Daily/Monthly Salary & $05 \%$ & $15 \%$ & $80 \%$ & $58 \%$ & $14 \%$ & $28 \%$ \\
\hline Allowances & $24 \%$ & $14 \%$ & $62 \%$ & $57 \%$ & $10 \%$ & $33 \%$ \\
\hline Salary Increments & $18 \%$ & $04 \%$ & $78 \%$ & $38 \%$ & $26 \%$ & $36 \%$ \\
\hline Overtime Payments & $17 \%$ & $08 \%$ & $75 \%$ & $51 \%$ & $13 \%$ & $36 \%$ \\
\hline Overtime Payments & $17 \%$ & $\mathbf{0 8 \%}$ & $75 \%$ & $51 \%$ & $13 \%$ & $36 \%$ \\
\hline Over target Payments \& Incentives & $01 \%$ & $09 \%$ & $90 \%$ & $85 \%$ & $15 \%$ & - \\
\hline Other Financial Facilities. & $24 \%$ & $14 \%$ & $62 \%$ & $48 \%$ & $38 \%$ & $14 \%$ \\
\hline Loan Facilities & - & - & $100 \%$ & $47 \%$ & $12 \%$ & $41 \%$ \\
\hline
\end{tabular}

Most plantation workers throughout the world enjoy some kind of non-wage benefits. By and large, they are placed at $20-25 \%$ of the basic nominal wage. According to the statistics, $71.5 \%$ of an employee's wage comprised of basic wage, which is the higher rate among the other tea producing countries, and $28.5 \%$ is allowances and other benefits, which are very low, compared to the other countries. Therefore, most of the workers who employ in plantation sector are unsatisfied with their non-wage benefits. Normally, the most of the tea plantation companies do not pay salary increments and do not provide any type of loan facilities for the state workers. The study reviews that most of these 
facilities were not improved or not considered by the management during the pre-privatization period. But after the privatization the most of the privatized plantations are implemented a salary incremental programmes, which are benefited to the employees. Further, the overtime payments are scheduled with the programme of over target payments \& incentives programme. Further, they implemented a programme for the employees to get a dividend payment annually and the amount of dividend depends on the employees' annual attendance. Further, with compare the pre-privatization period the daily/monthly salaries are improved up to certain level and reduced the number of hours and hours per week. These reasons directly affected to their attendance and productivity increment. Further, the study is proved that after privatization they are satisfied with the present remuneration structure to a certain level. These factors are also directly influenced to increase the labor productivity.

\section{Social \& Welfare Facilities}

Apart from the wages and other fringe benefits the social and welfare facilities provided to the employers also directly influence to improve the worker efficiency and the productivity. Housing, Education, Health, Transport, Shelter, Market, Water, Day Care Centers and Other Infrastructure Facilities can be identified as social welfare facilities. But the most of these facilities are directly provided or controlled by the central government and most of the above facilities are provided at a considerably satisfactory level. Housing, Education, Health, Electricity and Water facilities are totally provided by the central government. The companies provide $45 \%$ of the transport facilities and remaining is provided by the central government. After privatization of tea plantations, most of the companies have provided transport facilities, day care facilities, market facilities and health facilities. Further, the most of the tea plantation companies are engaged with the development of the infrastructure facilities because it provides benefits for both employees as well as management. In many case, estate residents are crowded into damp, smoky and dark hovels, severely affecting their health and creating enormous social and psychological stress. According to the field survey conducted by the Central Bank of Sri Lanka the percentage of self-ownership of housing in estate sector is $1.7 \%$. Housing for plantation workers is a universal problem. However, in Sri Lanka there is all-round progress but the pace is slow and will continue to be so. Further, the plantation companies are involved with this problem also up to certain level. The functions of the Social and Welfare Divisions of the two state corporations were handed over in 1993 to the Plantation Housing and Social and Welfare Trust in which the private companies have a majority representation. After this implementation and contribution of the plantation companies for the social and welfare facilities, there has been a remarkable improvement in the life and living condition of the plantation workers. 
Table 02. The Satisfactory Level of the Social and Welfare Facilities

\begin{tabular}{|c|c|c|c|c|c|c|}
\hline \multirow[t]{2}{*}{ Indicator } & \multicolumn{3}{|c|}{ Pre-privatization period } & \multicolumn{3}{|c|}{ Post-privatization period } \\
\hline & Satisfied & $\begin{array}{c}\text { Modera } \\
\text { te }\end{array}$ & $\begin{array}{c}\text { Un } \\
\text { satisfied }\end{array}$ & Satisfied & $\begin{array}{c}\text { Modera } \\
\text { te }\end{array}$ & $\begin{array}{c}\text { Un } \\
\text { satisfied }\end{array}$ \\
\hline Housing facilities & $20 \%$ & $10 \%$ & $70 \%$ & $25 \%$ & $15 \%$ & $60 \%$ \\
\hline Market facilities & $74 \%$ & $06 \%$ & $20 \%$ & $70 \%$ & $\mathbf{0 8 \%}$ & $22 \%$ \\
\hline Education facilities & $76 \%$ & $08 \%$ & $16 \%$ & $70 \%$ & $18 \%$ & $12 \%$ \\
\hline Health facilities & $84 \%$ & $09 \%$ & $07 \%$ & $95 \%$ & $05 \%$ & $00 \%$ \\
\hline Daycare Centers & $75 \%$ & $05 \%$ & $20 \%$ & $82 \%$ & $08 \%$ & $10 \%$ \\
\hline Transport facilities & $60 \%$ & $00 \%$ & $40 \%$ & $95 \%$ & $02 \%$ & $03 \%$ \\
\hline $\begin{array}{lll}\begin{array}{l}\text { Electricity } \\
\text { facilities }\end{array} & \& & \text { Water } \\
\end{array}$ & $81 \%$ & $11 \%$ & $\mathbf{0 8 \%}$ & $92 \%$ & $02 \%$ & $06 \%$ \\
\hline
\end{tabular}

In comparison to the pre-privatization and post-privatization periods, the satisfaction level of employees about those facilities is considerably increased because the plantation companies directly and indirectly have joined with the central government to develop those facilities up to a certain level. Especially, the privatized companies are highly involved with the target of improving the housing, health and transport facilities. Some companies provide a number of such facilities to their employees by using their own funds. Finally, this situation directly and indirectly affected the increase of labor productivity after privatization of tea plantations.

\section{Management Behavior}

Policy, institutional arrangements and their functions are determinants to administrative and management behavior in the tea sector as in any other sectors of the economy. Institutional arrangements include a set of labor regulations, duties, obligations, targets and responsibilities and these arrangements directly affected to the management efficiency. Productivity improvement in an enterprise is a function and a result of management efficiency, synonymous with good management. It is a prime management objective and responsibility to increase productivity and maintain its growth. In fact, creating the conditions for higher performances is the essence of productivity management.

According to the results of the field survey, more than $60 \%$ of the workers were on the opinion that there was a very tight administration in pre-privatization period. It is observed that they exercise very strict rules and regulations, compared to the post-privatized system. Especially, the long period of working hours, very high target, sealed working environment are the some of the reasons that affected to the employee-employer lower rapport. According to the study the unsatisfied level of the employer-employee relationship is very high i.e. $90 \%$. These poor conditions adversely affect labor productivity and the interaction among laborers. 
Table 03. Employees' Satisfactory Level about Management

\begin{tabular}{|c|c|c|c|c|c|c|}
\hline \multirow[t]{2}{*}{ Indicator } & \multicolumn{3}{|c|}{ Pre-privatization period } & \multicolumn{3}{|c|}{ Post-privatization period } \\
\hline & Satisfied & Moderate & $\begin{array}{c}\text { Un } \\
\text { satisfied }\end{array}$ & Satisfied & Moderate & $\begin{array}{c}\text { Un } \\
\text { satisfied }\end{array}$ \\
\hline Controlling System & $16 \%$ & $4 \%$ & $60 \%$ & $32 \%$ & $39 \%$ & $29 \%$ \\
\hline Work Load & $08 \%$ & $12 \%$ & $80 \%$ & $67 \%$ & $29 \%$ & $04 \%$ \\
\hline $\begin{array}{l}\text { Providing welfare } \\
\text { facilities }\end{array}$ & $40 \%$ & $28 \%$ & $32 \%$ & $58 \%$ & $34 \%$ & $08 \%$ \\
\hline Freedom & $28 \%$ & $20 \%$ & $52 \%$ & $39 \%$ & $29 \%$ & $32 \%$ \\
\hline $\begin{array}{l}\text { Number of rules and } \\
\text { regulations }\end{array}$ & $10 \%$ & $20 \%$ & $70 \%$ & $33 \%$ & $38 \%$ & $29 \%$ \\
\hline $\begin{array}{l}\text { Employer employee } \\
\text { relationship }\end{array}$ & $03 \%$ & $07 \%$ & $90 \%$ & $36 \%$ & $36 \%$ & $28 \%$ \\
\hline Industrial relations & $18 \%$ & $02 \%$ & $80 \%$ & $78 \%$ & $10 \%$ & $12 \%$ \\
\hline
\end{tabular}

On the other hand, the management controls the fieldwork by the subordinate staff and there is no direct link between management and the labor force. Thus, there is a flow of authority through the institutional arrangement from top to bottom. This presents a different pattern to that of modern industries where the labor force participates in target setting. This colonial arrangement of management structure and the institutional arrangements at estate level always undermine the motivation of field workers. However, this situation has been changed up to certain level with the changing policy environment and political ideologies of the economy after the privatization of the management.

The change in the employee's opinion on management directly affected to reduce the trade union actions in the plantation sector.

Table 04. Number of Strikes Involved and Man-days lost in Plantation Sector

\begin{tabular}{|l|c|c|c|c|c|c|c|}
\hline Item & 1985 & 1987 & 1989 & 1991 & 1992 & 1993 & 1994 \\
\hline Strikes & 132 & 64 & 45 & 111 & 86 & 26 & 89 \\
\hline Workers Involved & $\mathbf{5 0 8 4 0}$ & $\mathbf{2 0 1 8 8}$ & $\mathbf{1 5 0 7 2}$ & $\mathbf{5 6 8 5 6}$ & $\mathbf{4 7 7 1 2}$ & $\mathbf{4 5 5 9}$ & $\mathbf{2 7 5 7 5}$ \\
\hline Man days lost & $\mathbf{6 0 3 7 3}$ & $\mathbf{4 2 3 4 5}$ & 25619 & $\mathbf{9 9 2 3 7}$ & $\mathbf{2 4 4 7 0}$ & $\mathbf{8 0 0 7}$ & $\mathbf{3 8 3 8 7}$ \\
\hline
\end{tabular}

Source: Department of Census and Statistics, 1998.

The maintenance of industrial peace and cordial labor relations as the engine of progress in the labor intensive tea industry needs to be emphasized. In the Sri Lanka, The rights of workers are ensured not only through their highly organized trade union membership but also because of the far-reaching influence generated by the union and their leaders. But as was to be expected, the decision to privatize the estates was hardly welcomed by the trade unions. On the contrary, industrial harmony was breached and the post-June 1992 era has featured, although not major strikes, some degree of labor unrest involving minor and sporadic lockouts, threat to managerial personnel, police intervention, etc.

From the above-mentioned information, it can be concluded that the tight management of the pre-privatization period had reduced the job satisfactory of the employees in tea plantation and also it directly influenced to reduce the 
production and productivity, especially to reduce the labor productivity. Because the workers, their behavioral pattern on job, their responsibilities and duties are highly controlled by the management. But after the privatization of tea plantation this situation is changed up to certain level and the opinion about the controlling system, number of rules and regulations, freedom and work load is turned to more liberal position. Therefore, the management efficiency is a major factor that is directly influenced to the labor efficiency and further it can be increase through a successful motivation programme.

\section{Application of New Technology}

The total labor requirements of a tea estate are made up of the labor required for field operations and factory operations. In addition, labor is required for service activities such as transport. $99 \%$ of the field operations are labor oriented. The productivity of these field activities are influenced by the level of yield, the wage rate, terrain and experience of the activity. Application of new technology for improve the productivity in these activities are very less. For plucking section, coarse plucking may pluck a greater amount of leaves than fine plucking. For weeding, the chemical weeding is more effective and less cost than manual weeding. The amount of labor required for activities other than plucking and weeding constitutes a very small proportion of total field labor requirements per unit of land. Further, there are three major capital development activities, which are fairly labor intensive: replanting, new planting and filling of vacancies. Because of highly labor oriented activities and the less application of new technology the total productivity of field operations does not increase through technological or operating efficiency. Therefore, the labor productivity of field operations cannot increase through the operating or technological operations.

Factory labor demand is determined by the type of machineries, the extent of automation and new technology and the quantity of green leaves available for processing. In Sri Lanka majority of the tea factories are still working with old machineries. Only a few have modernized to a notable degree. Modernization to some extent has reduced the labor requirements for processing. Since the factory labor component is less than $10 \%$ of the total labor requirements per acre, even a total automation of the factory operations would not have a marked adverse effect on total employment in the tea industry. The most of the tea producing countries i.e. India, Kenya use these new technologies for all the processing steps but in our country the application of new technology is in low level.

Table 05. The Technology Applied by the Factories

\begin{tabular}{|l|c|c|}
\hline Operations & $\begin{array}{l}\text { Conventional } \\
\text { Technology }\end{array}$ & New Technology \\
\hline Pre-withering & $76 \%$ & $24 \%$ \\
\hline Withering & $71 \%$ & $29 \%$ \\
\hline Rolling & $53 \%$ & $47 \%$ \\
\hline Roll breaking & $51 \%$ & $49 \%$ \\
\hline Firing \& Drying shifting and & $81 \%$ & $19 \%$ \\
\hline $\begin{array}{l}\text { Grading, } \\
\text { packing }\end{array}$ & $33 \%$ & $67 \%$ \\
\hline
\end{tabular}


But most of the plantation companies are now introducing these new technologies with the support of foreign investment. Less efficient and more time consumed manual system has reduced the labor productivity. But after introducing the new technologies there is a significant improvement in production and productivity. This improvement is clearly highlighted after the privatization of plantation. Therefore, operating and manufacturing efficiency is an important factor that affects the labor productivity in tea plantations in Sri Lanka.

\section{Conclusion}

The study is aimed at identifying the reasons for the improvement of labor productivity in tea plantations after the privatization. Before the privatization of tea plantation the labor productivity of the most of the tea plantations were very poor. However, it can be conclude that there were a number of problems in tea plantations, which adversely affected to the growth of the productivity indices. Out of those various factors, the impact of worker efficiency, management efficiency and the manufacturing and technical efficiency towards the labor productivity are considered for this purpose in-depth.

The most important factor that affects to the labor productivity in tea plantations is the efficiency of the workers. Especially, the financial and welfare facilities provided to the employees directly affected to labor productivity in tea plantations. Most of the privatized companies improved the financial and nonfinancial facilities of labor such as wages and other fringe benefits. These facilities are at a satisfactory level up to certain level in comparison with the preprivatization period. The laborers usually face problems and obstacles in their social and welfare facilities. Especially their housing, education, health, transport, water supply and market facilities are not at a satisfactory level at the pre-privatization period. However, the privatized companies them selves and with the support of the government has improved these facilities up to certain level. These factors are directly and indirectly affected to increase the labor satisfaction.

The second major factor that affected to the labor productivity is efficiency of the management. After the privatization process of tea plantation there were changes in the management structure and in the pattern of management. It means that the colonial and institutional arrangements at estate level remain unchanged. The privatized tea plantation companies follow loose management policies with compare the pre-privatization period and a strong effort is made by the management to obtain optimum labor productivity by making the good employer-employee relationship. As a result of this attempt, the working environment and the satisfactory level of the employees about the management increased up to considerable level.

The third and the final factor that is considered in this study is technical efficiency. To get a higher rate of productivity from labors, highly developed modern technologies and machinery should be used. But the most of the field activities related to the tea production are labor oriented and cannot apply the new technologies. But the most of the privatized companies were taken the necessary steps to modernized there factories with the support of foreign investment. Less efficient and more time consumed manual system has reduced the labor productivity. But after introducing the new technologies there is a significant improvement in production and productivity. 
The lower level of satisfaction among the laborers about their wages and other fringe benefits, social and welfare facilities, and about the management style directly hindered the growth of labor productivity. But after the privatization of tea plantation the satisfactory levels about the above-mentioned factors increased up to considerable level. Therefore, it can be conclude that the improvement in satisfactory level of laborers directly affected to increase the total productivity and the labor productivity in tea plantation.

\section{References}

Bandara, Ranjith, R.W.T.M., 1996. The Present Status of Ecological Capital Management in the Tea Plantation Sector in Sri Lanka, An Exposition of the Concept with Illustrative Case Studies, Unpublished Working Paper, University of Colombo.

Bandara, Ranjith, R.W.T.M., 1997. The Present Crisis in the Tea Plantation Sector of Sri Lanka: Agro-Economical, Economic and Policy Perspective, Unpublished Working Paper, University of Colombo.

Central Bank of Sri Lanka, 1983, Report on Consumer Finances and SocioEconomic Survey, 1978/1979, Part I: Colombo.

Central Bank of Sri Lanka, 1984, Report on Consumer Finances and SocioEconomic Survey, 1981/1982: Sri Lanka, Part I: Colombo.

Central Bank of Sri Lanka, 1993, Report on Consumer Finances and SocioEconomic Survey, 1986/1987: Sri Lanka, Part I: Colombo.

Central Bank of Sri Lanka, 1996, Developments in the Tea Sector, January to June 1996: News Survey, June, Colombo.

Central Bank of Sri Lanka, 1998, Economic Progress of Independent Sri Lanka: Central Bank Press, Colombo.

Department of Census and Statistics, 1985, Labor Force and Socio-Economic Survey of Sri Lanka, 1989/1981: Colombo.

Department of Census and Statistics, 1987, Labor Force and Socio-Economic Survey, 1985/1986: Colombo.

Department of Census and Statistics 1988-1989, Economic \& Social Statistics of Sri Lanka: Colombo

Department of Census and Statistics 1993, Household Income \& Expenditure Survey 1990/1991: Colombo

Karunathilake, H.N.S., 1998, The Economy of Sri Lanka: Centre for Demographic and Socio-Economic Studies, Colombo.

Kelegama, S., 1993, Privatization in Sri Lanka: The Experience during the Early Years of Implementation: Unpublished Working Paper, Sri Lanka Economic Association, Colombo. 
Manikam P.P., 1995, Tea Plantations in Crisis: An overview, Unpublished Working Paper, Social Scientists' Association, Colombo.

People Bank, 1995, Productivity in Sri Lanka - The Macro Economic Environment: Economic Review, March, Colombo.

People Bank, 1997, Productivity Improvement and Concomitant Quality Enhancement, Economic Review, March, Colombo.

Sivaran B.H.D.P.B., 1996, Labor Economics in Tea: Unpublished Research, Tea Research Institute of Sri Lanka, Colombo. 